\title{
Izabela Rybka
}

Uniwersytet Papieski Jana Pawła II w Krakowie

\section{Praca socjalna w TeOril i dzialeaniu. SPRAWOZDANIE Z KONFERENCJI}

Konferencja naukowa Praca socjalna $w$ teorii i działaniu, 26-27 września 2017 roku, Kraków, Instytut Pracy Socjalnej Uniwersytetu Papieskiego Jana Pawła II w Krakowie.

Jesienią, w dniach 26-27 września 2017 roku, po raz czwarty w Instytucie Pracy Socjalnej Uniwersytetu Papieskiego Jana Pawła II w Krakowie odbyła się doroczna konferencja naukowa organizowana w ramach cyklu Praca socjalna $w$ teorii $i$ działaniu. Tym razem poświęcona była różnym aspektom starości, a w szczególności kwestiom wspierania osób starszych w taki sposób, aby w możliwie dobrej kondycji korzystały ze swoich praw oraz dobrodziejstw dostępnych w społeczności lokalnej. Konferencja Wsparcie seniora $w$ środowisku została zorganizowana przez Katedrę Etyki Pracy Socjalnej i Katedrę Pedagogiki Ogólnej we współpracy z Miejskim Ośrodkiem Pomocy Społecznej w Krakowie.

Katastrofa demograficzna w Polsce (i w Europie) oraz zmiany kulturowe stawiają przed nami kolejne wyzwanie - obowiązek zadbania o dobrostan osób starszych. W ich życiu zawodowym i rodzinnym następują zwykle zasadnicze zmiany - przechodzą na emeryturę, zaś dorosłe już dzieci zaczynają samodzielne życie na własny rachunek, nierzadko w innej miejscowości lub nawet innym kraju. Z kolei konsekwencją nadumieralności mężczyzn jest duża liczba wdów, które po śmierci męża i wyprowadzeniu się dzieci prowadzą jednoosobowe gospodarstwo domowe. Brak kontaktów społecznych i osób bliskich z jednej strony, z drugiej zaś pogarszający się stan zdrowia przy jednoczesnym spadku dochodów i poziomu lub jakości życia - wszystkie te okoliczności powodują, że osoby starsze potrzebują wsparcia, a nawet pomocy w codziennym funkcjonowaniu. Troska o godną starość wyraża się w zaspokajaniu wielorakich potrzeb osób starszych z ich udziałem, z poszanowaniem ich preferencji i wyborów. Osoby starsze z reguły chcą być „u siebie” - w swoim domu i wśród ludzi, których znają. Od rodziny wymaga 
to międzypokoleniowej solidarności, od znajomych i sąsiadów - oddolnych inicjatyw samopomocowych, zaś od władz publicznych - przemyślanej i konsekwentnie realizowanej polityki senioralnej. Jeśli jednak lokalna sieć wsparcia społecznego nie zapewnia wystarczającej pomocy, to osoby starsze coraz częściej zamieszkują w placówce oferującej całodobową opiekę, gdzie nadal powinny mieć możliwość utrzymywania relacji z rodziną i znajomymi oraz uczestniczenia w życiu społeczności lokalnej.

Celem konferencji było przedyskutowanie różnych rozwiązań zapewniających osobom starszym możliwie samodzielne funkcjonowanie w swoich mieszkaniach i środowiskach, a jeśli okaże się to niemożliwe - w placówce, która tworzy kameralne, prawie domowe warunki życia, jest otwarta na społeczność lokalną, współpracuje z wieloma podmiotami i odpowiada nie tylko na potrzeby bytowe. Konferencja miała charakter interdyscyplinarny - organizatorzy gościli pracowników naukowych z uczelni w całym kraju, prowadzących prace badawcze na temat starości w różnych dziedzinach wiedzy, takich jak pedagogika, socjologia, politologia, psychologia, filozofia, medycyna, nauki o rodzinie, prawo etc. Jednocześnie starali się zapewnić przyjazne miejsce spotkania i dialogu pomiędzy badaczami i nauczycielami akademickimi a środowiskami, które zawodowo lub wolontariacko pracują z osobami starszymi w ramach różnych podmiotów polityki społecznej, zwłaszcza pomocy społecznej, ochrony zdrowia, edukacji, kultury, rekreacji, zarówno z instytucji i władz publicznych, jak i organizacji pozarządowych. Nie zabrakło również osób starszych - organizatorzy chcieli bowiem uważnie wsłuchać się w ich głos i dowiedzieć się bezpośrednio od nich, czego potrzebują, co myślą o rozwiązaniach już realizowanych w praktyce i tych dopiero postulowanych. Zależało im również na tym, aby konferencja, jak również publikacja prezentująca jej dorobek, służyły promocji działań środowiskowych na rzecz seniorów, planowanych i realizowanych z udziałem samych seniorów oraz upowszechnianiu dobrych praktyk inspirujących do poszukiwania i wdrażania rozwiązań innowacyjnych, efektywnych, odpowiadających seniorom. W konferencji wzięło udział 165 osób, w tym 63 pracowników naukowych i 102 praktyków (z których część prowadzi również pracę naukową) oraz 20-30 seniorów, którzy uczestniczyli w kiermaszu, debacie lub brali udział w sesjach plenarnych i tematycznych.

Uroczystego otwarcia konferencji dokonali przedstawiciele władz uczelni i Instytutu Pracy Socjalnej w osobie Jego Magnificencji ks. prof. dr. hab. Wojciecha Zyzaka, rektora Uniwersytetu Papieskiego Jana Pawła II w Krakowie, ks. dr hab. Antoniego Świerczka, dziekana Wydziału Nauk Społecznych oraz dr hab. Małgorzaty Dudy, prof. UPJPII, Dyrektora Instytutu Pracy Socjalnej. Wykład wprowadzający w problematykę konferencji, zatytułowany Opieka w środowisku lokalnym a sytuacja demograficzna rodzin, wygłosiła prof. dr hab. Józefa Hrynkiewicz z Uniwersytetu Warszawskiego, przewodnicząca Rady do spraw Polityki Senioralnej. Następnie Stefan Kałucki, dyrektor Departamentu Polityki Senioralnej, w zastępstwie za dr Elżbietę Bojanowską, pracownika naukowego Uniwersytetu Kardynała Stefana Wyszyńskiego w Warszawie i podsekretarza stanu w Ministerstwie Rodziny, Pracy i Polityki Społecznej, przestawił referat System wsparcia osób starszych $w$ lokalnym środowisku.

Następnie odbyło się równolegle sześć sesji tematycznych, z których każda składała się z dwóch części. Organizatorom konferencji bardzo zależało na stworzeniu warunków 
sprzyjających włączaniu się w dyskusję skupioną wokół zagadnień prezentowanych w referatach. Zadbano, aby liczba referatów (zwykle osiem) i czas trwania poszczególnych sesji tematycznych (4 godziny zegarowe) umożliwiły uczestnikom podzielenie się wiedzą, doświadczeniami, refleksjami. Poniżej przedstawiamy tematy poszczególnych sesji oraz samodzielnych pracowników naukowych, którzy podjęli się ich moderowania:

- sesja I: Edukacja i inicjatywy seniorów, dr hab. Andrzej Niesporek, prof. Uniwersytetu Śląskiego;

- sesja II: Opieka medyczna i ustugi dla osób starszych, dr hab. Ewa Kucharska, prof. Akademii Ignatianum w Krakowie;

- sesja III: Gerontologiczna praca socjalna, dr hab. Dobroniega Trawkowska, prof. Uniwersytetu Adama Mickiewicza w Poznaniu;

- sesja IV: Polityka społeczna na rzecz seniorów, dr hab. Barbara Szatur-Jaworska, prof. Uniwersytetu Warszawskiego, dr hab. Tomasz Kaźmierczak, Uniwersytet Warszawski;

- sesja V: Duchowość i religia w życiu seniorów, dr hab. Małgorzata Duda, prof. Uniwersytetu Papieskiego Jana Pawła II w Krakowie; dr hab. Norbert G. Pikuła, prof. Uniwersytetu Pedagogicznego im. Komisji Edukacji Narodowej w Krakowie;

- sesja VI: Senior w przestrzeni medialnej, dr hab. Maria Straś-Romanowska, prof. Uniwersytetu Wrocławskiego, dr hab. Krzysztof Gurba, prof. Uniwersytetu Papieskiego Jana Pawła II w Krakowie.

Drugi dzień konferencji otworzyła sesja plenarna, podczas której zostały przedstawione referaty odnoszące się do tematyki sesji równoległych. Na szczególne wyróżnienie zasługuje wystąpienie Katarzyny Stec, zastępcy dyrektora MOPS ds. osób starszych i niepełnosprawnych w Gdyni, która przedstawiła nowatorskie sposoby współpracy pracowników socjalnych z osobami starszymi. Władze miasta i działające na jego terenie instytucje samorządowe oraz organizacje pozarządowe zapewniają osobom starszym nie tylko atrakcyjne sposoby spędzania czasu, ale również umożliwiają im nawiązywanie kontaktów i budowanie relacji z osobami z różnych grup wiekowych, wspólne przebywanie w miejskiej przestrzeni publicznej.

- Uczenie się w starości - edukacyjne inicjatywy seniorów na przykładzie Małopolski, dr hab. Zofia Szarota, prof. Uniwersytetu Pedagogicznego im. Komisji Edukacji Narodowej w Krakowie;

- Polityka senioralna czy polityka międzypokoleniowa?, mgr Katarzyna Stec, Miejski Ośrodek Pomocy Społecznej w Gdyni;

- Problemy rodziny w opiece nad człowiekiem starym niesprawnym, dr hab. Małgorzata Halicka, prof. Uniwersytetu w Białymstoku i dr hab. Jerzy Halicki, prof. Uniwersytetu w Białymstoku;

- Senior w mediach społecznościowych, dr hab. Krzysztof Gurba, Uniwersytet Papieski Jana Pawła II w Krakowie;

- Religijność osób starszych w Polsce. Wyniki badań statystycznych, dr hab. Paweł Ulman, Uniwersytet Papieski Jana Pawła II w Krakowie.

Na zakończenie konferencji organizatorzy oddali głos krakowskim seniorom, zarówno tym, którzy i obecnie, i przez całe życie byli zaangażowani w różne działania społeczne, jak i osobom, które dotąd skupiały się na rodzinie i na życiu zawodowym, 
zaś po przejściu na emeryturę i odejściu dorosłych dzieci z domu rodzinnego mają dużo czasu dla siebie i swoją aktywność realizują poza formami spędzania czasu zorganizowanymi przez dedykowane temu podmioty. W debacie wzięły udział Krystyna Łabuz, uczestnik przedsięwzięć organizowanych przez Fundację Uskrzydleni Wiekiem, w ramach której działa Centrum Aktywności Seniorów (CAS), Irena Szlachta, przedstawicielka Uniwersytetu Trzeciego Wieku z siedzibą na UPJPII, Barbara Szafraniec, członkini Krakowskiej Rady Seniorów i Ogólnopolskiego Porozumienia Rad Senioralnych, która jednocześnie od dawna prowadzi przyparafialną grupę charytatywną, oraz Ewa Czmyr wraz z dwiema koleżankami, które nie są związane z żadną instytucją działającą na rzecz seniorów. Debatę zatytułowaną Osoby starsze o swoich potrzebach i oczekiwanym wsparciu poprowadziły dr Izabela Rybka z Uniwersytetu Papieskiego Jana Pawła II w Krakowie i mgr Mirosława Zielony, dyrektor Powiatowego Centrum Pomocy Rodzinie w Koszalinie. Seniorki zostały poproszone o opowiedzenie, jak odnajdują się roli emerytek; co stanowi dla nich trudność, a co daje im radość życia? Czy w miejsce pracy zawodowej i obowiązków rodzicielskich pojawiły się nowe sprawy, osoby, aktywności społeczne? Czy w swoim lokalnym środowisku, wśród znajomych i sąsiadów, w ofercie działań organizacji społecznych i kościelnych oraz instytucji samorządowych, odnajdują odpowiedź na swoje potrzeby? W Krakowie jest bowiem wiele różnorodnych instytucji publicznych i organizacji sektora obywatelskiego, które zapewniają seniorom atrakcyjne i pożyteczne formy spędzania czasu z innymi ludźmi, przede wszystkim uniwersytety trzeciego wieku, kluby seniora, centra aktywności społecznej. Poza tym zastanawialiśmy się również nad tym, jak otworzyć przestrzeń publiczną czyniąc ją przystępną dla seniorów, w szczególności, co można i należy zrobić, żeby ich aktywność nie skupiała się w miejscach dedykowanych wyłącznie seniorom, ale również w miejscach otwartych dla różnych grup wiekowych, których oferta jest adresowana do ogółu mieszkańców.

Podczas dwudniowej konferencji pracownicy naukowi z licznych uczelni oraz osoby pracujące na co dzień z seniorami mówili o różnych aspektach życia osób starszych. Dyskusje pomiędzy uczestnikami konferencji, którzy wywodzą się z różnych środowisk zawodowych, tj. pracowników naukowych z praktykami systemu pomocy społecznej, były bezcennym atutem tej konferencji. Przyjęta przez organizatorów formuła cyklu konferencji Praca socjalna $w$ teorii i działaniu pozwala łączyć dwie perspektywy: teoretyczną z praktyczną, co pozwala na lepsze rozumienie potrzeb i sytuacji osób starszych, a jednocześnie umożliwia całościowe podejście do prezentowanych zagadnień. 